\title{
An Evaluation of the Effectiveness of Insurance Organizations at Providing Information to Policyholders: A Cross-Cultural Comparison between United Kingdom \& Turkey
}

\author{
Erdem Kirkbesoglu ${ }^{1}$, Jon $\mathrm{McNeill}^{2} \&$ Emir Huseyin Ozder ${ }^{1}$ \\ ${ }^{1}$ Faculty of Commercial Sciences, Baskent University, Ankara, Turkey \\ ${ }^{2}$ School for Business and Society, Glasgow Caledonian University, Glasgow, United Kingdom \\ Correspondence: Erdem Kirkbesoglu, Baskent University, Faculty of Commercial Sciences, Eskisehir Yolu \\ 20.km Etimesgut, Ankara, Turkey. Tel: 903-122-466-666. E-mail: erdemk@ baskent.edu.tr
}

Received: July 13, 2015

Accepted: August 6, 2015

Online Published: August 25, 2015

doi: 10.5539/ibr.v8n9p35

URL: http://dx.doi.org/10.5539/ibr.v8n9p35

\begin{abstract}
In the modern environment, accessibility and immediate access to information has become increasingly important. This is in part due to the increased ability of investors and policyholders' to access crucial information regarding insurance companies. Information relating to an insurers position, strength, strategy and outlook for example can exert influence on decision making towards the organization. This study therefore aims at testing the effectiveness of insurance companies to provide information to current and prospective policyholders in two separate international markets. To achieve this, we examine factors that can affect policyholders' decision making using the Analytic Hierarchy Process (AHP) for five insurance companies from the United Kingdom (UK) and Turkey. Companies were included based on having the highest GWP in their respective operating country. Insurance companies' did not have to operate in both countries to be included in this research. The results show that Turkish and UK insurance companies' demonstrate different responses based on the preset criteria. AHP results show that the companies prioritize different factors to achieve effective information sharing in the UK and Turkey.
\end{abstract}

Keywords: organizational effectiveness, insurance, analytic hierarchy process

\section{Introduction}

It is not physically possible (or desirable given that risk is opportunity) to eliminate risk from every-day life, this necessitated the development of strategies which allow society to mitigate and/or transfer the financial consequences of risk. To this end, insurance is one such a product that endeavours to achieve this through facilitating risk transfer between parties and its use, and dependency, has grown alongside society with respect to both individuals and businesses alike. A developed insurance market will provide significant funds to the host economy most notably through; the provision of investment capital, offsetting the possibility of financial ruin for policyholders, protect family income, manages risks, shares and diversifies loss across many parties both geographically and across lines of business and increases employment and productivity within economies by facilitating innovation, growth and development. Where insurance was once viewed as exiting to protect assets, its scope has grown and polices exist to preserve both revenues and profitability and plays a significant role in creating a resilient society. It can thus be concluded that many features of our modern society would not be possible without the existence of an insurance market which is both competitive and innovative.

A developed insurance market has a key role in the development of capital markets which in turn provide a flow of capital to the economy thus maintaining its health and promoting stable future growth. Therefore, it would be insufficient to regard insurance as simply a risk transfer mechanism spreading the losses from unfortunate events across several parties. Instead, the insurance industry has the capability to move resources and transfer risk and in doing so contribute greatly to economic growth and the effective allocation of resources. Additionally, it increases the effectiveness of financial systems through reducing operating costs, creating liquidity and establishing a scale economy effect on investments. Furthermore, a robust insurance industry reduces the pressure on State budgets by creating alternative products to the social security system. Life insurance policies and private retirement funds can 
be considered significant contributors of long-term funds to a nation's economy and this is especially the case in developing nations.

Given insurance is an effective technique for transferring the risks of all economic sectors (primary, secondary and tertiary) a developed insurance market has significant value to developing countries. This transfer of risk is possible through the availability, selection and purchase of an appropriate insurance policy covering against the potential loss of invested capital. For these reasons, and those outlined earlier, insurance can be considered an integral component for trade, industry and society due to the financial security it provides and as a fund producing force for financial activities. However, the significant impact of insurance markets on social and organizational life increases the need for insurance companies' to be reliable organizations.

An effective insurance market is established upon confidence. Current and prospective policyholder's confidence and trust in the market and products offered encourage wide participation resulting in a strong insurance marketplace. Furthermore, any customer who has confidence in insurance system ability to pay (counterparty risk is always present though historically unlikely in developed insurance markets) and believes in financial benefits it offers can input of fund and premium for a long time. These components help create a strong and sustainable insurance market characterized by vast participation and recurring business. Insurance companies which provide reliable financial support for policyholders, especially following loss and during the indemnity process, are fundamental to increasing the confidence level of policyholders in the marketplace. When the ability of insurers to honor claims comes into question this can often lead to regulation, such as Solvency II, which in part exists to maintain the confidence of stakeholders.

In contrast to historical patterns of behavior, the process of preparing or claiming an insurance policy are no longer the sole points of contact between policyholders and insurance companies. Traditionally, customers and insurers only have a minimal exchange which consequently meant that even straightforward administrative tasks can exert significant, and potentially disproportionate, influence on consumer confidence, perception and trust. As an example of the impact of this, the level of consumer trust in insurance companies was 70\%, in comparison to the $82 \%$ for banks (Ernst \& Young, 2014). This was largely attributed to be a consequence of the low frequency of contact between insurers and their customers and compounded by the finding that $44 \%$ of consumers had zero interactions with their insurer within the past 18 months. These infrequent interactions are perhaps understandable however, given that insurance is not only an intangible product but also one that most purchasers hope to never use. Indeed, it is the case in many countries that contact could be made regarding; new legal arrangements which could impact insurance companies and/or policyholders, promotions, offers of new insurance products, financial information, changes regarding the administration and capital, information regarding claim tracking and/or social responsibility projects. These are typical examples where information is shared with policyholders throughout the period of the policy and can serve to consolidate (or undermine) policyholder confidence in an insurance company and system as a whole.

In today's world, accessibility and immediate access to information has become increasingly important. This is in part because investors and policyholders' increased ability to access crucial information regarding the insurance companies position, strength, strategy and outlook for example, can exert influence on their decision making. Therefore, it is perhaps unsurprising that insurance companies have adjusted their approach and transitioned toward sharing more information through internet than previously.

This study aims at testing the effectiveness of insurance companies at providing information to current and prospective policyholders in two separate international markets. The United Kingdom insurance market writes the greatest sum of Gross Written Premiums (GWP) in the European Union and is the leading insurance market in comparison to its European Union counterparts and third largest in the world (Swiss Re-Sigma, No 3/2014). On the other hand, Turkey is a country which has made fundamental structural changes to its insurance system to become compliant with European standards to become an EU member. This study therefore considers these markets to be suitable for making intercultural comparison between developed and developing insurance markets.

\section{Organizational Effectiveness and the Dispersion of Information}

Today's economic environment makes survival of organizations difficult in a competitive world. Organizations must undertake structural changes to lessen environmental pressures caused by these competitive pressures. For organizations to adapt to their environments and then prosper, it is imperative that organizational design is of a sufficient quality to serve organizational purpose and achieve goals. Organizational efficiency and legitimacy correlate not only with inter-organizational actions but also with a stable and trusting environment inside the organization (MacDuffie, 2011). Therefore, determination of the capabilities and qualities for organizational success and effective organizational structure is of great significance when operating within a rapidly changing 
environment where competition is ever increasing. Within this scope, for successful decisions and ongoing effectiveness, it is therefore essential that organizations adopt an understanding of both information and technology.

Insurance companies interact with many actors (such as rivals, suppliers, customers, shareholders, trade unions, government etc.) with respect to both its internal and external environment. This not only assists in developing the intellectual capital of the insurer but also permits the transference of organizational information to its customers and shareholders. At this point, the purpose is to gain competitive advantage through the dissemination of information effectively. Thanks to the rapid developments in information technology and environmental variables over the past decade, information has become an immensely significant resource at facilitating and developing sustainable competitive advantage (Porter \& Millar, 1985; Powell \& Dent-Micallef, 1997; Mata et al., 1995). In the modern environment, information can be considered as a tool for creating additional value for customers, facilitating their living and even making it more enjoyable whilst simultaneously increasing both their awareness and knowledge through education. It is therefore in the interests of the insurance company to do this as effectively as possible through their website.

The organization is continuously in a two-way interaction with its environment both gathering information from it and provides information to it (Zack, 2003). Organizations obtain information from their customers, society, education and research institutions and even from their competitors. The information garnered can sometimes be so valuable that a given organization can achieve competitive advantage. Some examples include; substantial productivity growth, a noticeable decrease in costs, opportunities for new customers or new markets and product/process novelties. Insurance companies can benefit from this two-way information given the finding that far more insurance consumers actually switch insurers than express an intention to switch (Ernst \& Young, 2014) This lack of forewarning creates difficulties for insurance companies and by garnering information on customers through their websites this could be one way to manage this phenomenon. Despite developed market insurers being more sophisticated in understanding consumer habits it is clear from these findings that website information could be better used to assist effectiveness.

While it is often not mandatory for organizations to share the information they obtain, it can be advisable as sharing information is often necessary to inform relevant stakeholders who could be impacted by the operating environment of the organization. For example, customers, investors, suppliers and competitors are often sensitive to the content of information organizations would typically share. It is also of critical importance to convey correct information to the appropriate people at the appropriate time. In accordance with the principles of enlightening society and transparency, organizations are often inclined to facilitate the sharing of information where it seeks to enhance customer satisfaction and commitment. In recent times, customers have grown particularly sensitive to the transparency and reliability of organizations from which they purchase products or receive services from. This is because the relationship between the organization and customer is not just confined to the process of sale. Customer expectancy and customer demands extent for a long time following any sale. In an insurance context, contact could occur across different phases of the customer relationship lifecycle including; education and research, decision and purchase, maintenance and service, claims, close or renewal (Ernst \& Young, 2014). Therefore it can be held that, while organizations can enhance their reliability during pre-sale process by sharing information with customers, the opportunity also exists to enhance customer loyalty during post-sale process. To achieve this, the most frequently applied method by today's insurance companies is by way of websites (Majtanova \& Brokesova, 2012). Through websites, it can be observed that organizations have the potential to interact with existing and potential customers and stakeholders and this applies to both national and international markets. It is thus arguably both necessary and advantageous that modern customers can access the content of any product or service, their characteristics, post-sale support, relevant forms and usage instructions.

As a consequence of rapid technological development coupled with an insatiable demand for the internet, more and more potential customers, now have access to the internet (Poela \& Leunisb, 1999). It is therefore worthwhile to consider the capabilities of the current and potential consumers of insurance as this will impact how they choose, access and process insurance products and information as per the overarching objective of this study. According to data available from the World Bank (2013) 89.8\% of the population in the UK had access to the internet while in comparison only $46.4 \%$ of the population had access to the internet in Turkey. The UK's superiority in this respect is not only limited to levels of internet penetration but also with respect to speeds attainable. According to 2014 figures released by Akamai Technologies, who conduct an annual 'State of The Internet' Report, the UK's average connection speed stands at $10.7 \mathrm{Mbit} / \mathrm{s}$ whereas the Turkish average 'lags' at 5.5 Mbit/s. These figures have implications for the number of consumers the information reaches and also how 
the information can be presented. In 2014, 38 million adults (76\% of total) in Great Britain accessed the Internet every day, 21 million more than in 2006, when directly comparable records began. Access to the Internet using a mobile phone more than doubled (from $24 \%$ to 58\%) between 2010 and 2014 in UK. Moreover $74 \%$ of all adults in UK bought goods or services online in 2014. It could be anticipated therefore that UK insurers would prioritize interactivity and ergonomics when choosing how to best present information to consumers in comparison to Turkish insurers who may offer simpler approach due to the differences in internet speeds. It can be held that the continued development of communications and internet technology has refocused the activities of enterprises forcing them to adapt their strategy to comply with internet-age demands. The influence of internet technology has impacted organizations across various fields. With specific reference to insurance companies, a notable effect can be observed when considering their marketing activities and how the internet has altered both their understanding of marketing and how operations have been modified to reflect its understanding. One significant change is how the internet has become a popular distribution channel for insurers as opposed to simply a vehicle for presenting information.

A great variety of products/services including insurance, banking, publishing, visual activities and computer applications are completely produced and priced on internet and their promotion and delivery are conducted solely via the internet. For this reason, the use of websites has become a leading outlet for insurance companies seeking to promote their products and services through internet-based marketing activities. Additionally, websites are fundamentally useful communication channels for conveying contact information to customers. It is therefore held that the characteristics and the content of individual websites, prepared by insurance companies, can be a potential source of competitive advantage in the pursuit of new customers and the retention of existing ones.

To achieve competitive advantage, it is essential that insurers understand what customers are seeking and how they surf the internet. Accurately answering these questions can provide indicators regarding customers' preferences regarding what they find interesting and the kind of conveniences the websites should provide e.g. how insurers can satisfy their customers. This can be achieved firstly through analysis of the demographic structure and the interests/needs of website visitors and then by applying a process called 'segmentation'. Segmentation can be considered as the identification of portions of the market that are different from one another. Theoretically, segmentation will allow insurance companies to better satisfy the needs of their customers by tailoring the information it provides.

The rapid increase of new websites coupled with the influx of additional information creates considerable challenges for insurance companies to effectively provide the information sought by internet users. For this reason, enterprises aim at building websites with user-friendly content. It has long been recognized that trust is a key ingredient in fostering economic and financial transaction and achieving business success (Guiso, 2012). Especially in sectors such as insurance where a trust-based relationship plays an important role, the information contained on insurers' websites should be understandable, accessible and reliable. Furthermore, trust is arguably important because counterparty risk would only become evident after a period of time following the purchase of the policy. Further still, trust is tied to the idea that insurance is itself an intangible product as when insurance is purchased it is merely a promise of indemnity sometime in the future.

\section{Regulations Towards Web-based Information Sharing in United Kingdom and Turkish Insurance Industry}

To maximize the opportunities presented by the internet, organizations must go beyond merely building a website which is merely fit for purpose. Instead, it is essential insurance companies present an effective internet page which is unique and is capable of creating and adding value (Cronin, 1996). For example, when online sales made by insurance companies are compared with sales made through agencies which utilize the internet as a distribution mechanism, it is observed that internet sales can offer a 23\% cost advantage (Yanık \& Yazici, 2002). Consequently, significant cost advantages can be realized by organizations who adopt this approach when using the internet as a mechanism to communicate and disseminate information. Practical evidence of this exists as the share of premiums now accounted for by online sales has increased in many countries (Swiss Re, 2014), especially in lines such as motor insurance where the nature of cover has become increasingly standardized. The developed UK motor insurance market in particular has been transformed by the internet and it could therefore be anticipated that the Turkish market has the potential to reflect these changes as it transitions towards a more developed state.

The promotion and sale of insurance products on the internet in developed markets such as the UK are significant. This represents a transition from websites being used solely to convey information as is often the 
case in developing markets. The internet and websites therefore have become increasingly important as a mechanism for presenting information and facilitating distribution of insurance products. Direct internet sales now account for around $20 \%$ of all UK personal motor insurance both in terms of premiums and number of policies (Swiss Re, 2014) having displaced the telephone as the dominant sales medium. It is therefore unsurprising that a wide array of insurance companies now provide online services to their customers. This can be explained in part by a greater appreciation by managers of the impact of competitive factors on electronic trade and thus increased awareness of both opportunities and threats offered by the internet with respect to trading purposes.

Adoption and use of the internet by Turkish insurance companies has gradually increased and developed over the past decade. It should be noted however that e-commerce insurance premiums are currently considered minor and the penetration of insurance e-commerce is less successful when compared to other industries. This is evidenced by the fact that in the European Union (EU) e-commerce accounts for less than 5\% of insurance purchases (Swiss Re, 2014) in comparison with approximately $14 \%$ of total sales across all sectors (Europa Community Survey, 2013).

There are many reasons existing and potential customers may visit an insurers website. The reasons include; inquire about obtaining a new policy, obtain information about the policy, details of premium increases on a current policy, information related to switching policy to another insurer, to dispute the resolution of a claim, follow up the status of a claim, or to update information e.g. address. It is suggested that this type of information should be accessible on through the insurance company home page. Investors on the other hand can also become empowered through the use of the information on websites, simple access to financial and economic news, current and past data, carry out comparative analysis of competitor performance and conduct basic research regarding the investment targets. Furthermore, investors may desire links to previous accounts to evaluate ratios such as; expense ratio, loss ratio, combined operating ratio, insurance margin and Minimum Capital Requirements to assess the insurance companies' financial health.

Currently many developing countries, such as Turkey, aim at harmonizing their insurance system to align with EU norms. The historical relationship between the EU and Turkey can be traced over a period of forty years however discussions and involvement have intensified since full membership negotiations began in 2005. Following this process, as has been required in many industries, the Turkish insurance industry was required to achieve a quality which could be considered appropriate by EU norms. Resultantly, in order to integrate Turkey's insurance market to the EU, numerous laws and regulations have come into being since 2007. Throughout this process, insurance legislation has been drafted and redrafted. The pool systems related with insurance (e.g. Agriculture Insurance Pool, Natural Disaster Insurance Entity) were established and it was ensured that by means of establishing insurance information centers (e.g. Motor Vehicle Insurances Information Center, Center for Historical Claims, Health and Life Insurances Information Center) a wealth of reliable statistics were collected so that insurance fraud in addition to those not insured could be identified. In addition, new organizations (e.g. Insurance Education Center) came into being to improve insurance training and several adverts and consequently promotions regarding insurance appeared in social media to raise public awareness. In comparison with Turkey, in the UK the relationship between insurers and the provision of pensions is long standing and is exemplified by $47 \%$ of the working population currently contributing to a pension (ABI, 2014). Furthermore, 20.7 million individual pension policies were in force in 2013 (ABI, 2014) and of 26.4 million households in the UK in 2012, 5.7 million had whole of life assurance, 2.5 million had a personal pension, 1.1 million had a non-mortgage-related endowment, 0.8 million had a mortgage-related endowment, 0.7 million had term insurance and 0.4 million had income protection (ONS, 2012). These figures are only attainable in developed insurance markets alongside effective regulation. They perhaps also simultaneously explain both the desire of the Turkish government to develop their market and transfer these social risks (pensions) and why the EU requires this harmonization of standards prior to allowing entry given the level of policyholder capital at risk.

Developed insurance markets within the EU have considerably greater regulatory quality. With respect to the two countries in this study, this is evidenced by the Lloyds market benchmark which attributes scores of $95 \%$ and $66 \%$ to the UK and Turkey respectively (Lloyds, 2014a; Lloyds 2014b) and the 29\% gap perhaps demonstrating the gap between developed and developing insurance markets and so the need for harmonization. From the perspective of government, the goal in creating new regulation is undoubtedly the creation of an insurance market which inspires stakeholder confidence through reliable (low counterparty risk) and transparent operations. Thus, effective regulation can be considered as vital to ensuring policyholders have sufficient confidence to purchase insurance products.

Regulation of the financial services in the UK from 2000 Until April 2013 UK insurers was carried out by a single body i.e. the Financial Services Authority (FSA), which was set up to replace multiple regulatory bodies 
as a way of streamlining. However, the FSA has since been succeeded by two new regulatory bodies; The Prudential Regulatory Authority (PRA) which regulates vital facets of the financial strength of financial organizations and The Financial Conduct Authority (FCA) which regulates the behavior of these same financial organizations. In the case of insurance companies and other large financial institutions such as banks, these are regulated by both the PRA and FCA. The FCA and PRA are accountable to the UK Treasury (which has charge over the UK's financial system) and Parliament. They are independent bodies and therefore do not receive any funding from the government. Other bodies with responsibilities related to the financial services sector include; the Financial Ombudsman Service (FOS) which was established by the government as a free independent body to settle complaints between customers and financial service companies where the firm is unable to resolve an issue themselves. A recent example of the value of the FOS can be seen with reference to the miss-selling of Payment Protection Insurance (PPI) (see McConnell \& Blacker (2012)) in which "millions of people have already complained about PPI miss-selling and billions of pounds have already been paid out in compensation" (Financial Ombudsman Service, 2014). In the event a customer is entitled to compensation but the company cannot honor the claim, the Financial Services Compensation Scheme (FSCS) exists as an independent body to assist in resolving this. Additionally, The Monitory Advice Service (MAS) is an independent body which endeavors to improve people's understanding and knowledge of financial matters (including the UK financial system) with the goal of improving consumer confidence in their own ability to manage their own finances. Finally, and specifically to insurers, The Association of British Insurers (ABI) represents the UK's insurance, long term savings and investment industry (ABI, 2014b) and communicates on behalf of insurers and provides consumers of insurance with information on related financial products and services. It is therefore apparent the UK insurance market has many mechanisms in place to support a stable insurance market representing the interest of insurance companies and consumers alike.

According to EU laws with which Turkish insurers must now comply, insurance companies are required to provide more information to their customers and create an appropriate website. The subsequent regulations issued by the Turkish government pertaining to the provision of information to policyholders has unsurprisingly resulted in Turkish insurance companies affording greater attention to the content of their websites. According to Insurance Law in Turkey, it is now expected that all insurance companies share the following information in Turkey through their website (Regulations Regarding Inform in Insurance Contracts, 2007):

- Partnership structure, administrative structure and the capital of insurer notably general information about the insurer

- General information about the branches, services and products in which the company operates

- Information concerning the compensation demand process

- Information regarding tax practices

- Address, electronic mail, telephone and fax number

- Contact addresses for agencies, telephone and fax number

- Forms and procedures for complaints and applications

- All Electronic forms

- Statistical data and further information.

The regulations which are now in force are part of Turkey's harmonization efforts towards chieving the EU's aims for transparency for all insurance policyholders. In this sense, the case of Turkey represents a country which aspires to adopt the EU's approach as a model of good practice through compliance with its standards. Conversely, the UK is a long established and leading actor within the European insurance market. Within this scope, our purpose is to compare the criteria of EU membership and candidate countries specifically with respect to expectations of providing information to policyholders. On this basis, cross-cultural differences faced by both countries in the course of providing information to policyholders will be tested.

\section{Methodology}

\subsection{Data}

Insurance companies endeavour to make effective use of websites in order to attract new customers and retain existing customers by successfully meeting their information needs. With respect to these needs, it can be understood that customers expect information to be readily, speedily and easily accessible and available. For this reason, it is expected that the websites of the insurance companies currently satisfy these customers' needs.

In this study, the characteristics which should be part of the website of any insurance company are presented according to four categories. Each of these criteria has also sub criteria within themselves. In the application part of this study, whether the Turkish and the UK insurance companies have a website content regarding the criteria 
indicated in Table 1 has been questioned. Criteria to justify inclusion in this study-GWP to benchmark size of insurance company. It is noted that using the GWP as a benchmark of size has some limitations namely;

i. It is a benchmark of the total premium (direct $\&$ assumed) written by an insurer before reinsurance deductions and any ceding commissions.

ii. It does not imply collected, but the gross policy premium to be collected as of the issue date of the policy, regardless of the payment plan.

Despite these limitations, GWP is a commonly used and understood benchmark of insurer size and therefore it was considered adequate for the purposes of this research in terms of being an acceptable benchmark for inclusion.

Consequently, five insurance companies which have the highest GWP production (Insurance Information Institute, 2015) and operate in Turkey and United Kingdom have been incorporated into the research scope. These insurance companies constitute the majority of insurance market in both countries. AXA, Aviva, Direct Line Group, RSA Group, Zurich insurance companies are selected for UK. On the other hand, Allianz, AXA, Anadolu, Ak, Mapfre Genel insurance companies were chosen to comprise the representative sample for Turkey. Accordingly, it is proposed that it is possible to draw generalizable inferences about the insurance sector of each country.

Table 1. Data set of the study

\begin{tabular}{|c|c|c|}
\hline \multirow{16}{*}{ INFORMATION (I) } & Main Page Info (MPI) & Are the needs of visitor fulfilled on home page at first glance? \\
\hline & Headline $(\mathrm{H})$ & Does it have the content which can attract the attention about the company? \\
\hline & $\operatorname{Logo}(\mathrm{L})$ & Does it have any distinctive characteristic? Is it catchy? \\
\hline & Motto (M) & Does it define the purposes of the institution? \\
\hline & Advertisement (AD) & Does it fulfil the needs of the customer? \\
\hline & News \& Announcements (N\&A) & Is it updated? \\
\hline & Communication Info (CI) & $\begin{array}{l}\text { Is it possible for the customers to reach to the company through telephone, } \\
\qquad \text { fax or internet? }\end{array}$ \\
\hline & Address Info (RI) & Is it possible to access the addresses of company? \\
\hline & Security Info (SI) & $\begin{array}{l}\text { Are the risks which can pose threat for the customers defined under this } \\
\text { title? }\end{array}$ \\
\hline & On-line Access $(\mathrm{OA})$ & Is it possible to access to the forms and documents online? \\
\hline & Founding Date (FD) & Is the date of establishment indicated? \\
\hline & Mission \& Vision (M\&V) & $\begin{array}{l}\text { Is the targeted position of company in the future indicated? Is the reason } \\
\text { why it has targeted this position indicated? }\end{array}$ \\
\hline & Branch Office Address (B\&AI) & Is it possible to reach to the regional directorates and agencies? \\
\hline & Financial Statement (FS) & $\begin{array}{l}\text { Is the financial information which can fulfil the expectancy of investors } \\
\text { shared? }\end{array}$ \\
\hline & Board of Directors (M\&M) & Is the top management of the company defined? \\
\hline & Products $(\mathrm{P})$ & Are the company's insurance products defined clearly? \\
\hline \multirow{4}{*}{ ERGONOMIC (E) } & Site Map (SM) & Is it possible to view the whole content of the website in a single page? \\
\hline & Search Engine (SE) & Is there any search engine that would facilitate to search? \\
\hline & Main Page Button (MPB) & Is there any button that would facilitate returning to the main page? \\
\hline & Language Variety (LV) & Are the pages in different languages available? \\
\hline \multirow{4}{*}{ ACCESS (A) } & Up to Datedness (UTD) & When the website was last updated? \\
\hline & Security \& Confidentiality (S\&C) & $\begin{array}{l}\text { Are there any factors that would have an impact on the confidence of } \\
\text { customer who visits website? }\end{array}$ \\
\hline & Loading Speed Quality (LSQ) & Is the speed of website loading and turning its pages adequate? \\
\hline & Comprehensibility (C) & $\begin{array}{l}\text { Is the information on the website's homepage sufficient enough to be } \\
\text { understood by the customers? }\end{array}$ \\
\hline \multirow{4}{*}{ DEPENDENCY (D) } & Frequently Asked Questions (FAQ) & $\begin{array}{l}\text { Are the answers of the questions that are frequently asked by the customers } \\
\text { available on website? }\end{array}$ \\
\hline & Survey/Complain/Request (SCR) & $\begin{array}{l}\text { Are online request forms in which the customers can express their opinions } \\
\text { available? }\end{array}$ \\
\hline & Social Media Links (SML) & $\begin{array}{l}\text { Does the company have any page orientation to the frequently used pages } \\
\text { in social media? }\end{array}$ \\
\hline & Current News $(\mathrm{CN})$ & Is there any share regarding sectorial news? \\
\hline
\end{tabular}


One of these categories demonstrates the quality of sharing basic information about the insurance company on the website. Ergonomic criteria include those characteristics which have an impact on the ease of use of each websites. Websites should be easy to navigate and it should also be straightforward to access all desired information. Accessibility criteria are those which enable the customers to access the websites rapidly, easily and clearly. With respect to loyalty criteria, they are considered to be those which make the customers' use the website on a recurring basis thus requires features which attract and hold their attention.

Ten insurance companies which were determined within the scope of this study were analysed by three academics and were evaluated according to how successfully they fulfilled the criteria indicated in Table 1. Referees attributed weighted points ranging from 1 to 9 in accordance with the availability and the quality of the criteria. Accordingly, while 1 point demonstrates non-existence of the criterion, 9 points demonstrate its availability qualitatively.

\subsection{Analysis: AHP (Analytic Hierarchy Process)}

The Analytic Hierarchy Process (AHP) is an often used solution technique for solving any multi-criteria decision making problems. This technique was first proposed by Thomas L. Saaty in the 1970's and is used to solve complex multi-criteria decision making problems. The AHP technique makes a choice from many alternatives by means of a pairwise comparison matrix with respect to that hierarchical structure (Saaty, 1980). In other words, AHP is applied to give relative importance values to the decision alternatives and criteria in an otherwise complex decision making process.

This technique can be considered a descriptive modelling technique which utilizes rating scales for calculations. The success of this technique stems from its simplicity, intelligibility and applicability for the different situations (Gok, 2006). In decision making processes the evaluation appraisal should be achieved using a mathematical model. AHP allows decision-makers to take into account the different situations of psychological and sociological observations or rational and irrational choices in decision-making mechanisms (Dagdeviren et al., 2004; Saaty \& Vargas, 1987). The decision-making process with the Analytic Hierarchy Process typically consists of the following stages (Saaty, 1994).

Step 1-Defining The Decision Problem: Identification of decision-making problems comprises two stages. Decision points in the first step are detected. In other words, judgment will be made regarding how many results are sought to answer the question. In the second phase, the factors affecting the decision point are determined. In this study, $m$ denotes the number of decision point's, while the number of factors that influence the decision point is symbolized by $n$. Accurate determination of a number of factors will influence the result and so making a detailed description of each factor is important to ensure a more consistent and logical binary comparison.

Step 2-Creating The Comparison Matrix between Factors: Factors from comparison matrix form a square matrix. Matrix components on the diagonal of this matrix takes the value 1. Components on the diagonal of the comparison matrix also take the value 1 as the relevant factor is compared with itself. Comparison of factors is performed according to their importance with respect to each other. This comparison is made verbatim and mutual. In comparisons of the factors the scale in Table 2 is used.

For example, if the first factors are considered more important when making the comparison with the third factor, the first row of the third column in this case comparison matrix component $(i=1, j=3)$, it will take a value of 3 . Otherwise the comparison to the third factor that is the first factor, the more important preferred first line of the matrix to be used since in this case the comparison component will be the third column of the third factor value of $1 / 3$. If the comparison is equal then the value entered will be the value of the first factor.

Step 3-Determination of Significance Percentage Breakdown of Factors: The comparison matrix indicates the importance level of each factor following certain logic. However, in order to determine the weight of all these factors, it uses column vectors which constitute the comparison matrix. The B-column $\mathrm{n}$ and $\mathrm{n}$ component vector is generated.

Step 4-Consistency Rate Measurement: Although AHP Technique has a systematic approach; the results can be inconsistent because of the decision maker's subjectivity on verifying the factors. Consequently, the consistency rate is measured and inconsistent data are revised.

Step 5-Finding a Percentage to Importance of Distribution in M Decision Point for Each Factor: One to one comparison and matrix operations are repeated until equal to the number of factors ( $\mathrm{n}$ times).

Step 6-Finding the Distribution of the Results on the Decision Point: For the final step of the application results are gathered and presented according to values. 
Table 2. Importance scale

\begin{tabular}{|c|c|c|}
\hline $\begin{array}{l}\text { Intensity of } \\
\text { Importance }\end{array}$ & Definition & Explanation \\
\hline 1 & Equal Importance & Two activities contribute equally to the objective \\
\hline 2 & Weak or slight & \\
\hline 3 & Moderate importance & $\begin{array}{l}\text { Experience and judgement slightly favour one activity over } \\
\text { another }\end{array}$ \\
\hline 4 & Moderate plus & \\
\hline 5 & Strong importance & $\begin{array}{l}\text { Experience and judgement strongly favour one activity over } \\
\text { another }\end{array}$ \\
\hline 6 & Strong plus & \\
\hline 7 & Very strong or demonstrated importance & $\begin{array}{l}\text { An activity is favoured very strongly over another; its } \\
\text { dominance demonstrated in practice }\end{array}$ \\
\hline 8 & Very, very strong & \\
\hline 9 & Extreme importance & $\begin{array}{l}\text { The evidence favouring one activity over another is of the } \\
\text { highest possible order of affirmation }\end{array}$ \\
\hline $\begin{array}{l}\text { Reciprocals of } \\
\text { above }\end{array}$ & $\begin{array}{l}\text { If activity } i \text { has one of the above non-zero } \\
\text { numbers assigned to it when compared with } \\
\text { activity } j \text {, then } j \text { has the reciprocal value when } \\
\text { compared with } i\end{array}$ & A reasonable assumption \\
\hline $1.1-1.9$ & If the activities are very close & $\begin{array}{l}\text { May be difficult to assign the best value but when compared } \\
\text { with other contrasting activities the size of the small numbers } \\
\text { would not be too noticeable, yet they can still indicate the } \\
\text { relative importance of the activities }\end{array}$ \\
\hline
\end{tabular}

Source: Saaty, T. L. 2008. Decision making with the analytic hierarchy process. Int. J. Services Sciences, Vol. 1, No. 1.

\section{Findings}

In the previous section, we modified Bursali (2010) and Dyussemaliyeva's (2011) scales to verify the efficiency of websites using preset criteria. In this study 29 criteria were chosen with the help of questionnaire. Researchers opted to examine 4 main and 29 sub-main criteria within these. These criteria were determined by the needs of the carriers and were included in the model. Efficiency criteria's are given in Table 1.

Table 3. Weighted scores of top ten criteria for insurance companies from UK and Turkey

\begin{tabular}{cccccc}
\hline \multicolumn{2}{c}{ United Kingdom } & \multicolumn{3}{c}{ Turkey } \\
\hline Criteria & Category & Weighted Scores & Criteria & Category & Weighted Scores \\
\hline Security \& Confidentiality & Information & 0,096 & Founding Date & Information & 0,077 \\
Site Map & Ergonomic & 0,095 & Advertisement & Information & 0,069 \\
Search Engine & Ergonomic & 0,095 & Mission \& Vision & Information & 0,068 \\
Loading Speed Quality & Access & 0,072 & Communication Info & Information & 0,055 \\
Main Page Info & Ergonomic & 0,051 & Branch Office Address & Information & 0,055 \\
Logo & Information & 0,05 & Products & Information & 0,055 \\
Up to Datedness & Access & 0,05 & Address Info & Information & 0,054 \\
Financial Statement & Information & 0,049 & On-line Access & Information & 0,054 \\
Security Info & Information & 0,049 & Financial Statement & Information & 0,052 \\
Communication Info & Information & 0,044 & Loading Speed Quality & Access & 0,04 \\
Headline & Information & 0,042 & Search Engine & Ergonomic & 0,035 \\
News \& Announcements & Information & 0,035 & Site Map & Ergonomic & 0,035 \\
\hline Board of Directors & Information & 0,033 & Headline & Information & 0,034 \\
Products & Information & 0,028 & Logo & Information & 0,034 \\
\hline
\end{tabular}

AHP calculations were made sequentially. UK and Turkish insurance companies' importance value percentage can be viewed in Table 3 below. When Table 3 is analyzed, it attracts attention that the five most significant criteria for the UK are Security \& Confidentiality, Site Map, Search Engine, Loading Speed Quality and Main Page Info. On the other hand, when it comes to Turkey, five most significant criteria are listed as Founding Date, 
Advertisement, Mission \& Vision, Communication Info and Brand \& Address Info. More clearly, it has been observed that insurance companies attach importance to the different criteria when providing information to policyholders. While UK based insurers place greater emphasis on access, ergonomics and information, it can be observed that Turkish insurance companies attach importance to the criterion of information. Thus this study concludes that insurance companies target different criteria contextually and pay attention to the different criteria while providing information to policyholders. Furthermore, based on these results it can be proposed that the pressure exerted upon insurance companies by "Regulations about providing Information to the Policyholders" can be indicated as a reason why Turkish insurance companies consider the criterion of information more significant. For this reason, it is observed that, while providing information to policyholders, the Turkish insurance companies are using the factor related to 'information' much more in comparison to the other factors.

As can be seen from the results, Turkish and UK insurance companies' demonstrate different responses based on the preset criteria. AHP results show that the companies use different factors to be effective in the process of information sharing in UK and Turkey. On the other hand, the level of effectiveness is also approximately equal and homogeneous for the countries. According to the criteria weighting, all companies' classification are given in Table 4 below.

Table 4. AHP result

\begin{tabular}{cc}
\hline AHP Result & Insurance Companies \\
\hline 0,2308 & Turkey 2 \\
0,2175 & Turkey 1 \\
0,2136 & United Kingdom 5 \\
0,2123 & United Kingdom 3 \\
0,2114 & Turkey 3 \\
0,2105 & United Kingdom 2 \\
0,1823 & United Kingdom 4 \\
0,1813 & United Kingdom 1 \\
0,1741 & Turkey 4 \\
0,1660 & Turkey 5 \\
\hline
\end{tabular}

\section{Conclusion}

The insurance industry supplies a flow of funds to the economy in developed and developing countries. It also creates resources through these funds which are transferred through investment, prevents financial ruin, enhances the level of income, directs risks, shares loss, increases productivity within economy and encourages growth and development.

Insurance system is established upon confidence. The policyholder's confidence about the system encourages them to take part in this system for many years. Policyholders are not only in touch with the insurance companies in the course of preparing the damage and insurance policy. In today's modern countries, policyholders can get information from the insurance companies due to several reasons. Especially in many countries, legal arrangements about policyholders, promotions, new insurance types, financial information, changes regarding the administration and capital, information about damage tracking and/or social responsibility projects are shared with policyholders and it consolidates policyholder's confidence about the system. In today's world, an immediate access to information and the accessibility are even more significant. This is because the access of the investors and policyholders to crucial information about the insurance companies can have an influence on the decisions in future.

For this reasons, this study aims at testing the effectiveness of insurance companies at providing information to current and prospective policyholders in two separate international markets. British and Turkish insurance industries was compared in terms of effective usage of internet sites. AHP is a convenient technique that allows to determine decision-makers' choice of destination correctly and it provides an easy decision making process. The reason of the using of AHP method in this study is to verify most efficient way to inform customers for insurance companies. Because the results obtained by the AHP allows for the determination of the company that provides the best way to communicate with customers. Moreover results can be presented to other insurance companies as an example. It also offers structural and contextual differences between UK and Turkey. The reason that AHP method is dependent on expert analysis with industrial knowledge, it provides the reflection of 
the cultural and sectoral factors.

The results show that Turkish and British insurance companies' demonstrate different responses based on the preset criteria. AHP results show that the companies use different factors to be effective in the process of information sharing in UK and Turkey. The results indicate that model/sample insurance companies in both countries use different communication channels and methods. In addition, It is observed that British insurance companies are much more homogeneous and they have various ways to inform customers compared with Turkish companies. There are two main limitations of the study. Firstly, gathering more expert opinion may increase on the reliability of the study. Secondly, increasing the number of the insurance companies can provide more comprehensive benchmarking with model/sample company.

\section{References}

Akamai. (2014). Akamai's State of the Internet: Q2 2014 Report. Retrieved on July 3, 2015 from http://www.economiza.com/wp-content/uploads/akamai-soti-a4-q214.pdf

Association of British Insurers (ABI). (2014a). UK Insurance Key Facts 2014. Retrieved on July 6, 2015 from https://www.abi.org.uk/ /media/Files/Documents/Publications/Public/2014/Key\%20Facts/ABI\%20Key\%20 Facts\%202014.pdf

Association of British Insurers (ABI), (2014b). About us ABI. Retrieved from https://www.abi.org.uk/About

Dağdeviren, M., Akay, D., \& Kurt, M. (2004). İş Değerlendirme Sürecinde Analitik Hiyerarşi Prosesi ve Uygulaması. Gazi Üniversitesi Mühendislik Mimarllk Fakültesi Dergisi, 19(2), 131-138.

Ernst, \& Young. (2014). Reimagining customer relationships: Key findings from the EY Global Consumer Insurance Survey 2014. Retrieved on July 3, 2015 from http://www.ey.com/Publication/vwLUAssets/ey-2014-global-customer-insurance-survey/\$FILE/ey-global-c ustomer-insurance-survey.pdf

EY.

(2014).

Retrieved from

http://www.ey.com/Publication/vwLUAssets/ey-2014-global-customer-insurance-survey/\$FILE/ey-global-c ustomer-insurance-survey.pdf

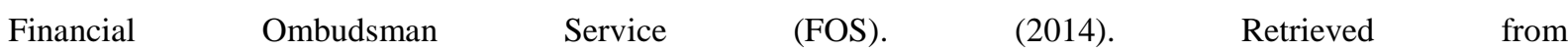
http://www.financial-ombudsman.org.uk/contact/PPI-your-case.html

Gök, M. (2006). Analitik Hiyerarşi Yöntemini Kullanan Bir Karar Destek Yazılımının Gelişstirilmesi. Yüksek Lisans Tezi, Muğla Üniversitesi Fen Bilimleri Enstitüsü.

Guiso, L. (2012). Trust and insurance markets. Economic Notes, 41(1/2), 1-26. http://dx.doi.org/10.1111/j.1468-0300.2012.00239.x

Insurance Information Institute (III). (2015). 2015 International Insurance Fact Book. III-Insurance Information $\begin{array}{llllll}\text { Institue. } & \text { Retrieved } & \text { on } & \text { July } & 10, & \text { from }\end{array}$ http://www.iii.org/sites/default/files/docs/pdf/international_insurance_factbook_2015.pdf

Lloyds, (2014a). Country Profile UK. Lloyds. Retrieved on July 8, 2015 from http://www.lloyds.com/ /media/files/the\%20market/tools\%20and\%20resources/new\%20market\%20intellig ence/country\%20profiles/europe/gb_mi_2014_12_03\%20country\%20profile.pdf

Lloyds. (2014b). Country Profile-Turkey. Lloyds. Retrieved on July 7, 2015 from https://www.lloyds.com/ /media/files/the\%20market/tools\%20and\%20resources/new\%20market\%20intelli gence/country\%20profiles/europe/tr_mi_2014_04_17_country\%20profile.pdf

MacDuffie, J. P. (2011). Inter-organizational trust and the dynamics of distrust. Journal of International Business Studies, 42, 35-47. http://dx.doi.org/10.1057/jibs.2010.54

Majtanova A., \& Brokesova, Z. (2012). Financial Services Marketing In the Era of Online Social Network Sites: The Case of Insurance Marketing. Ekon. Misao Praksa Dbk. 21(1), 45-66.

Mata, F. J., Fuerst, W. L., \& Barney, J. B. (1995). Information Technology and Sustained Competitive Advantage: A Resource-Based Analysis. MIS Quarterly, 19(4), 487-506. http://dx.doi.org/10.2307/249630

McConnell, P., \& Blacker, K. (2012). Systemic operational risk: the UK payment protection insurance scandal. The Journal of Operational Risk, 7(1), 79-139.

Poela, D. V., \& Leunisb, J. (1999). Consumer Acceptance of the Internet as a Channel of Distribution. Journal of Business Research, 45(3), 249-256. http://dx.doi.org/10.1016/S0148-2963(97)00236-1 
Porter, M. E., \& Millar, V. E. (1985). How information gives you competitive advantage. Harvard Business Review, 63(4), 149-160.

Powell, T. C., \& Dent-Micallef, A. (1997). Information technology as competitive advantage: The role of human, business, and technology resources. Strategic Management Journal, 18(5), 375-405. http://dx.doi.org/10.1002/(SICI)1097-0266(199705)18:5<375::AID-SMJ876>3.3.CO;2-Z

Saaty, T. L. (1980). The Analytic Hierarchy Process. New York: McGraw-Hill.

Saaty, T. L. (1994). How to Make a Decision: The Analytic Hierarchy Process. Interfaces, 24(6), 19-43. http://dx.doi.org/10.1287/inte.24.6.19

Saaty, T. L. (2008). Decision making with the analytic hierarchy process. Int. J. Services Sciences, 1(1). http://dx.doi.org/10.1504/ijssci.2008.017590

Saaty, T. L., \& Vargas, L. G. (1987). Uncertainty and Rank Order in the Analytic Hierarchy Process. European Journal of Operational Research, 32, 107-117. http://dx.doi.org/10.1016/0377-2217(87)90275-X

Swiss, R. (2014a). Sigma No 3/2014 - World insurance in 2013: Steering towards recovery. Swiss Re. Retrieved on July 1, 2015 from http://www.tsb.org.tr/images/Documents/sigma3_2014_en.pdf

Swiss, R. (2014b). Sigma 2/2014-Digital distribution in insurance: A quiet revolution. Swiss Re. Retrieved on July 102015 from http://media.swissre.com/documents/sigma2_2014_en.pdf

The Financial Ombudsman Service. (2014). PPI-your case with us. Retrieved on July 5, 2015 from http://www.financial-ombudsman.org.uk/contact/PPI-your-case.html

The Office of National Statistics (ONS). (2015). Family Spending, 2012 Edition-ONS. Retrieved on July 10, 2015 from http://www.ons.gov.uk/ons/rel/family-spending/family-spending/family-spending-2012-edition/index.html

The World Bank. (2015). Internet users (per 100 people) Data Table. Retrieved on July 2, 2015 from http://data.worldbank.org/indicator/IT.NET.USER.P2

Zack, M. H. (2003). Rethinking the knowledge-based organization. Sloan Management Review, 44(4), 67-71.

\section{Copyrights}

Copyright for this article is retained by the author(s), with first publication rights granted to the journal.

This is an open-access article distributed under the terms and conditions of the Creative Commons Attribution license (http://creativecommons.org/licenses/by/3.0/). 